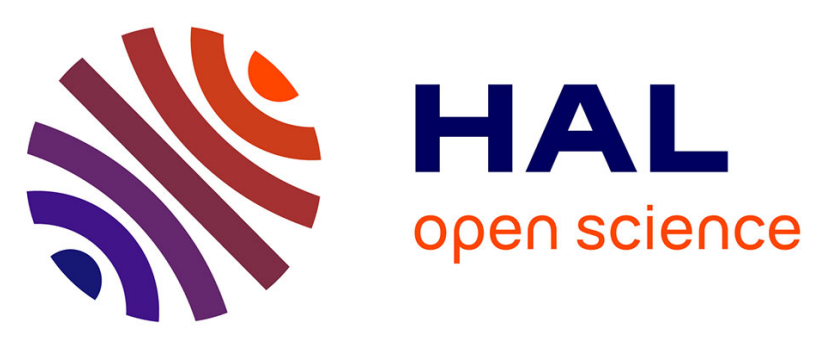

\title{
Four human breast cancer cell lines with biallelic inactivating gene mutations
}

Antoinette Hollestelle, Fons Elstrodt, Mieke Timmermans, Anieta M.

Sieuwerts, Jan G. M. Klijn, John A. Foekens, Michael A. Bakker, Mieke

Schutte

\section{To cite this version:}

Antoinette Hollestelle, Fons Elstrodt, Mieke Timmermans, Anieta M. Sieuwerts, Jan G. M. Klijn, et al.. Four human breast cancer cell lines with biallelic inactivating gene mutations. Breast Cancer Research and Treatment, 2009, 122 (1), pp.125-133. 10.1007/s10549-009-0545-4 . hal-00535395

\section{HAL Id: hal-00535395 \\ https://hal.science/hal-00535395}

Submitted on 11 Nov 2010

HAL is a multi-disciplinary open access archive for the deposit and dissemination of scientific research documents, whether they are published or not. The documents may come from teaching and research institutions in France or abroad, or from public or private research centers.
L'archive ouverte pluridisciplinaire HAL, est destinée au dépôt et à la diffusion de documents scientifiques de niveau recherche, publiés ou non, émanant des établissements d'enseignement et de recherche français ou étrangers, des laboratoires publics ou privés. 


\title{
Four human breast cancer cell lines with biallelic inactivating $\alpha$-catenin gene mutations
}

\author{
Antoinette Hollestelle $\cdot$ Fons Elstrodt $\cdot$ Mieke Timmermans $\cdot$ \\ Anieta M. Sieuwerts · Jan G. M. Klijn · John A. Foekens • \\ Michael A. den Bakker $\cdot$ Mieke Schutte
}

Received: 10 July 2009/ Accepted: 3 September 2009/Published online: 18 September 2009

(C) Springer Science+Business Media, LLC. 2009

\begin{abstract}
Mutations of E-cadherin have been identified in half of lobular breast cancers and diffuse-type gastric cancers, two tumor subtypes with remarkably similar pathological appearances including small rounded cells with scant cytoplasm and a diffuse growth pattern. A causal role for E-cadherin gene mutations in the lobular breast cancer phenotype was recently demonstrated in E-cadherin knock-out mice. These observations suggested that another gene in the E-cadherin tumor suppressor pathway might be mutated in lobular breast cancers with wild-type E-cadherin genes. Here, we identified E-cadherin gene mutations exclusively in human breast cancer cell lines that grow with a rounded cell morphology. Using expression analyses and gene mutation analyses, we have identified four biallelic inactivating $\alpha$-catenin mutations among 55 human
\end{abstract}

Electronic supplementary material The online version of this article (doi:10.1007/s10549-009-0545-4) contains supplementary material, which is available to authorized users.

A. Hollestelle $(\bowtie) \cdot$ F. Elstrodt $\cdot$ M. Timmermans ·

A. M. Sieuwerts · J. G. M. Klijn · J. A. Foekens .

M. Schutte $(\square)$

Department of Medical Oncology, Josephine Nefkens Institute,

Erasmus University Medical Center, P.O. Box 2040,

3000 CA Rotterdam, The Netherlands

e-mail: a.hollestelle@erasmusmc.nl

M. Schutte

e-mail: a.schutte@erasmusmc.nl

J. A. Foekens

Cancer Genomics Centre, Rotterdam, The Netherlands

M. A. den Bakker

Department of Pathology, Josephine Nefkens Institute, Erasmus

University Medical Center, Rotterdam, The Netherlands breast cancer cell lines. All four $\alpha$-catenin mutations predicted premature termination of the encoded proteins, and concordantly, none of the four mutant cell lines expressed $\alpha$-catenin proteins. Importantly, three of the $\alpha$-catenin mutant cell lines had the rounded cell morphology and all 14 cell lines with the rounded cell morphology had mutations of either E-cadherin or $\alpha$-catenin. As anticipated, loss of $\alpha$-catenin protein expression was associated with the lobular subtype in primary breast cancers. Together, our observations suggest that $\alpha$-catenin may be a new tumor suppressor gene that operates in the E-cadherin tumor suppressor pathway.

Keywords Cell adhesion - Cell morphology ·

E-cadherin · Lobular breast cancer .

Tumor suppressor gene

\section{Introduction}

The E-cadherin/catenin protein complex consists of the cytoplasmic proteins $\alpha$-catenin, $\beta$-catenin, $\gamma$-catenin, and p120-catenin (p120ctn) and the transmembrane protein E-cadherin. The armadillo proteins $\beta$-catenin and $\gamma$-catenin bind directly to the intracellular carboxy-terminal tail of E-cadherin and p120ctn binds more membrane-proximal to E-cadherin. The vinculin-related protein $\alpha$-catenin acts as a molecular switch and binds either to $\beta$-catenin or $\gamma$-catenin as a monomer or to the actin cytoskeleton as a homodimer. Extracellular, E-cadherin forms homodimers with E-cadherin proteins on adjacent epithelial cells in a calcium-dependent fashion. The E-cadherin/catenin protein complex thus maintains the integrity of epithelial tissues through cell-cell adhesion (reviewed in $[1,2]$ ). 
Inactivation of the E-cadherin tumor suppressor gene in human cancer may involve mutational inactivation or transcriptional silencing by transcriptional repressors and/or promoter hypermethylation (reviewed in [3-5]). Mutations in the E-cadherin gene had predominantly been found in breast cancers of the lobular subtype, but also in diffuse-type gastric cancers, two tumor subtypes that have remarkable similarities in their morphological appearance [6-9]. The association of E-cadherin gene mutations with this typical morphology suggested causality for E-cadherin mutations. Indeed, mutational inactivation of $E$-cadherin has been shown to be causal for a lobular cancer phenotype in conditional knock-out mice [10]. However, not all human lobular breast cancers harbor E-cadherin mutations. We therefore hypothesized that another gene in the E-cadherin pathway might be mutated in these tumors.

Here, we have used a model of 55 human breast cancer cell lines to study E-cadherin inactivation. We found an exclusive association of $E$-cadherin gene mutations with a characteristic rounded cell morphology of the mutant cell lines. We then identified biallelic inactivating $\alpha$-catenin gene mutations in E-cadherin wild-type cell lines with the rounded cell morphology.

\section{Materials and methods}

\section{Breast cancer cell lines}

The 55 human breast cancer cell lines used in this study are listed in Table 1. Cell lines EVSA-T, MPE600, and SKBR-5/7 were kind gifts of Dr. N. de Vleesschouwer (Institut Jules Bordet, Brussels, Belgium), Dr. H.S. Smith (California Pacific Medical Center, San Francisco, CA, USA) and Dr. E. Stockert (Sloan-Kettering Institute for Cancer Research, New York, NY, USA), respectively. The SUM cell lines were generated in the Ethier laboratory (available at http://www.asterand.com). Cell lines OCUB-F and $-\mathrm{M}$ had been generated from the same tumor, and were obtained from Riken Gene Bank (Tsukuba, Japan). The other cell lines were obtained from ATCC (Manassas, VA, USA). All cell lines were grown in RPMI 1640 medium supplemented with $10 \%$ fetal bovine serum, in standard culture flasks.

\section{Clinical breast cancers}

Formalin-fixed paraffin-embedded primary breast cancers included 33 lobular, 48 ductal, 22 medullary, 22 mucinous, and 14 tubular breast cancers. All 139 breast cancers were obtained from the archive of the Pathology department at Erasmus MC, randomly selected from diagnosis years 1990 through 2005 based on their histology. Tissue microarrays (TMAs) were constructed by punching three 0.6-mm cores from representative areas of each tumor and transferring them into a recipient paraffin block using an ATA-27 automated tissue microarrayer (Beecher Instruments, Sun Prairie, WI, USA). The Medical Ethical Committee at Erasmus MC has approved the study (MEC 02-953), which was carried out according the Code of Conduct of the Federation of Medical Scientific Societies in the Netherlands (http://www.fmwv.nl).

Gene mutation analysis

E-cadherin and $\alpha$-catenin (ENSG00000039068 and ENSG00000044115) coding sequences were analyzed by direct sequencing of PCR-amplified fragments from genomic DNA, using an ABI3100 Genetic Analyzer (Applied Biosystems, Foster City, CA, USA) and intronic primers (Supplementary Table S1). All identified mutations were confirmed by sequencing of an independently amplified DNA template and all deletions were confirmed by performing a duplex PCR including primers for the ZEB2 gene (ENSG00000169554) that served as positive control.

Promoter methylation analysis

Methylation specific PCR (MSP) for E-cadherin CpG1 and CpG3 was done using the EZ Methylation Kit (Zymed, Orange, CA) with reported primers [11] under our standard PCR conditions [12]. For azacytidine assays, exponentially growing cells were treated for 3 days with $10 \mu \mathrm{M} 5$-aza- $2^{\prime}$ deoxycytidine (Sigma, Steinheim, Germany) and total RNA was isolated on day 4 using the RNeasy kit (Qiagen, Hilden, Germany).

\section{Expression analysis}

Reverse transcriptase (RT)-PCR for E-cadherin, $\alpha$-catenin, $\beta$-catenin, $\gamma$-catenin, and p120ctn was done using the Qiagen one-step RT-PCR kit and gene-specific exonic primers (Supplementary Table S2).

Immunohistochemistry was performed using the EnVision+ kit (DAKO, Glostrup, Denmark). To unmask antigens, slides were boiled for $20 \mathrm{~min}$ in Citrate buffer at pH 6 (Klinipath, Duiven, The Netherlands) for $\alpha$-catenin or Tris-EDTA buffer at $\mathrm{pH} 9$ (Klinipath) for the other antigens. Primary monoclonal antibodies and their dilutions were: E-cadherin 1:25 (DAKO, clone NCH-38), $\alpha$-catenin 1:40 (Santa Cruz Biotechnology (Santa Cruz, CA, USA), clone G-11), $\beta$-catenin 1:100 (BD Transduction Laboratories (Franklin Lakes, NJ, USA), clone 14), $\gamma$-catenin 1:120 (BD Transduction Laboratories, clone 15), 


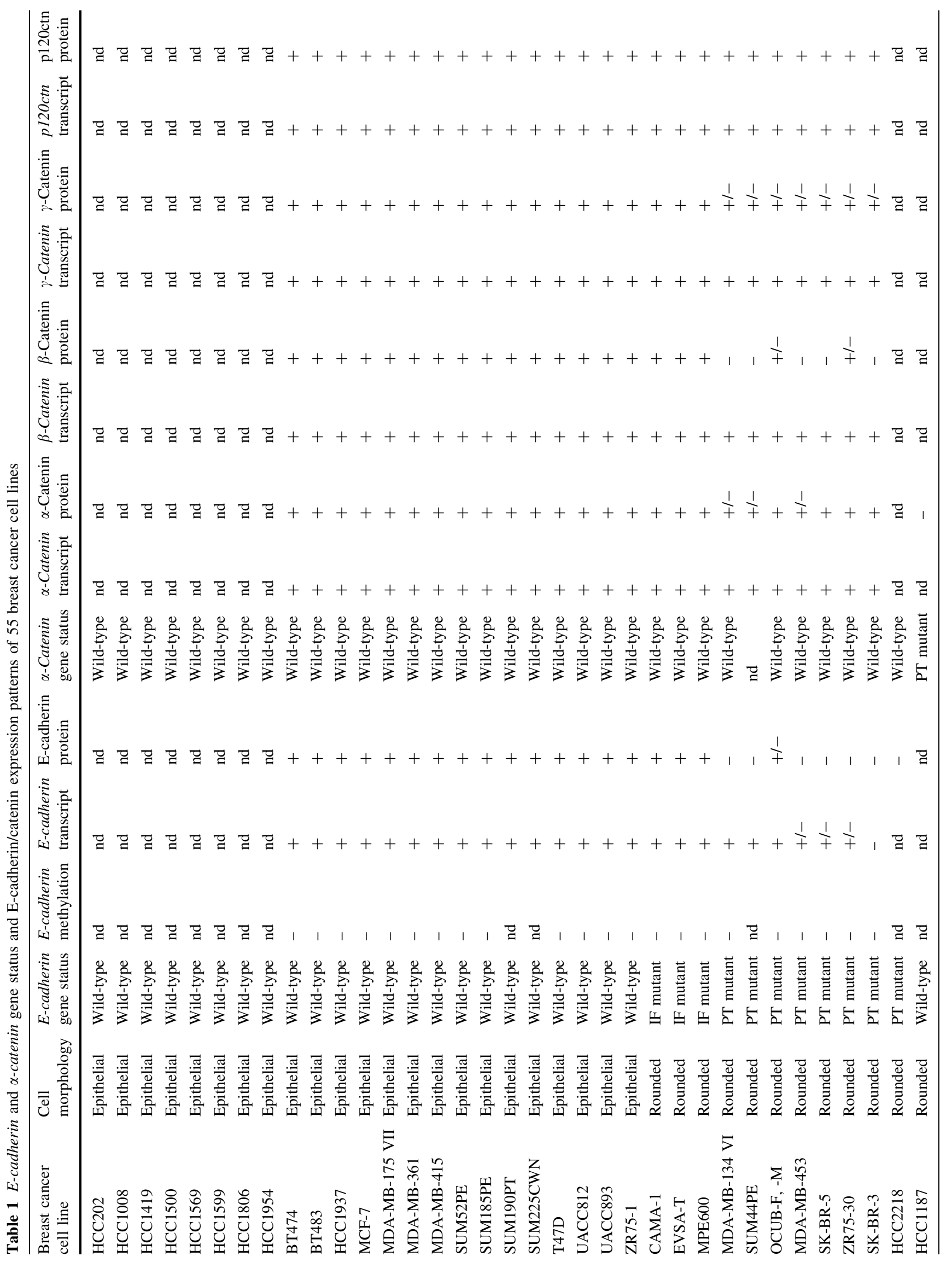




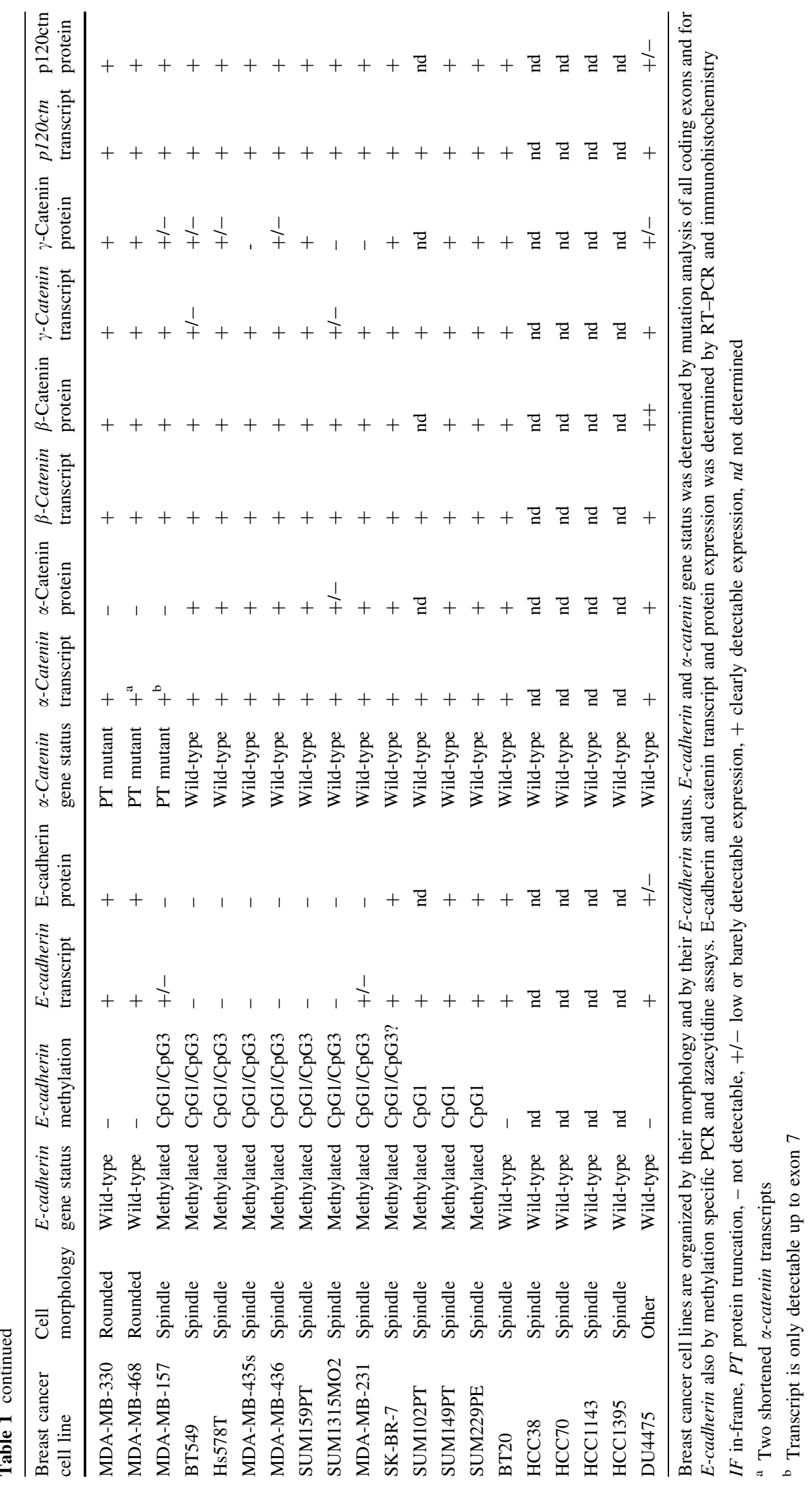


and p120ctn 1:150 (BD Transduction Laboratories, clone 98).

\section{Results}

E-cadherin gene mutations are found exclusively among breast cancer cell lines with rounded morphology

We have used a model of 55 human breast cancer cell lines to study E-cadherin inactivation. The E-cadherin gene status was analyzed for gene mutations by sequencing and for promoter methylation by MSP and azacytidine assays. Together, 11 E-cadherin mutant cell lines and 12 cell lines with methylation at the E-cadherin gene promoter were identified (Table 1, mutations detailed in [13] and c.1_1565del1565 in HCC2218). Three distinct morphology groups were apparent among the breast cancer cell lines: those that grow with epithelial cells, with rounded cells, and with spindle cells (Fig. 1, Table 1). Importantly, all 11 E-cadherin mutant cell lines had the rounded cell morphology, whereas all 12 E-cadherin methylated cell lines had the spindle cell morphology. All cell lines with the epithelial cell morphology had a normal E-cadherin gene status. The two different inactivation mechanisms of E-cadherin thus appear to have a profound impact on cell morphology.

E-cadherin gene mutations are identified in half of lobular cancers, but essentially not in other subtypes of breast cancer [6, 7, 14]. The presence of non-cohesive small rounded cells with scant cytoplasm is a cytological characteristic of the lobular pathological subtype of human breast cancer [15]. Concordantly, mutations in E-cadherin were shown to be causal for the lobular subtype of breast cancer [10]. Indeed, the rounded cell morphology of the breast cancer cell lines is characterized by rounded cells with scant cytoplasm. The rounded cells may grow in clusters, grape-like bunches or so-called Indian files of cells, or as single cells (Fig. 1). The cell cultures typically also contain adherent cells that grow in epithelial sheets but these display diminished cell-cell adhesion. The proportion of rounded cells versus adherent cells varies per cell line (ranging from 10 to 90\%), and the rounded cells may be attached to the adherent cells or float freely in the culture medium. The 14 breast cancer cell lines with the rounded cell morphology thus appear to resemble lobular breast cancers. Consistent with this notion, four E-cadherin mutant cell lines from our collection were known to be derived from breast cancers with lobular characteristics (EVSA-T, MDA-MB-134VI, MDA-MB-330, and SUM44PE; [16-18] and personal communication Dr. S.P. Ethier).
Truncating $\alpha$-catenin mutations in four human breast cancer cell lines

Although E-cadherin mutation was shown to be causal for the lobular subtype of breast cancer, not all lobular breast cancers harbor E-cadherin mutations [6, 7]. Similarly, three rounded breast cancer cell lines from our collection had wild-type E-cadherin genes, suggesting that mutations in another gene of the E-cadherin tumor suppressor pathway might be involved. To seek evidence that another gene in the E-cadherin pathway might be mutated, we performed expression analysis of $\alpha$-catenin, $\beta$-catenin, $\gamma$-catenin, and p120ctn by RT-PCR and immunohistochemistry on cell line TMAs (Table 1). Interestingly, four wild-type E-cadherin cell lines had lost $\alpha$-catenin protein expression and two of these cell lines also had a shortened $\alpha$-catenin transcript. Subsequent analysis of the complete coding sequence of $\alpha$-catenin revealed four biallelic $\alpha$-catenin mutations among 55 human breast cancer cell lines. In cell line MDA-MB-468, $\alpha$-catenin exons 4 and 5 were homozygously deleted from the genome, resulting in two aberrant transcript lengths (Fig. 2a; c.302_588del287). One transcript lacked exons 4 and 5, predicting a premature termination of the encoded $\alpha$-catenin protein (r.302_588del287; p.D102IfsX8). The other transcript lacked exons 3 through 5 , predicting an in frame deletion of 161 amino acids (r.106_588del483; p.V36_Q196del161). As we did not detect $\alpha$-catenin protein expression in MDA-MB-468 with a C-terminal antibody, it appears that the second transcript is not being translated. In cell line MDA-MB-157, we were not able to amplify $\alpha$-catenin exons 8 and 9 from the genome (Fig. 2b). Using various combinations of intronic and exonic primers for both exons 8 and 9, we never observed PCR amplification products for exon 8 and, depending on the primer combination, shorter or no amplification products for exon 9. Transcript analysis by RT-PCR allowed amplification of exons 1 through 7, but none of the more $3^{\prime}$ located exons. Together, these results suggested a complex genomic rearrangement or translocation in MDA-MB-157, involving deletion of $\alpha$-catenin exon 8 and partial deletion of exon 9. Finally, cell lines HCC1187 and MDA-MB-330 both harbored a nonsense mutation (Fig. $2 \mathrm{c}$ and $\mathrm{d}$; c.2032C $>$ T/p.Q678X and c. $1322 \mathrm{C}>$ G/p.S441X, respectively). Additionally, we identified two SNPs and two silent mutations in 22 cell lines (Supplementary Table S3). Regrettably, original (uncultured) tumor material was not available for any of the four $\alpha$-catenin mutant breast cancer cell lines, precluding confirmation that the mutations had been present in the original tumors. Together, we identified four biallelic $\alpha$-catenin mutations among 55 breast cancer cell lines.

Importantly, three of the four $\alpha$-catenin mutant breast cancer cell lines have the rounded cell morphology. All 

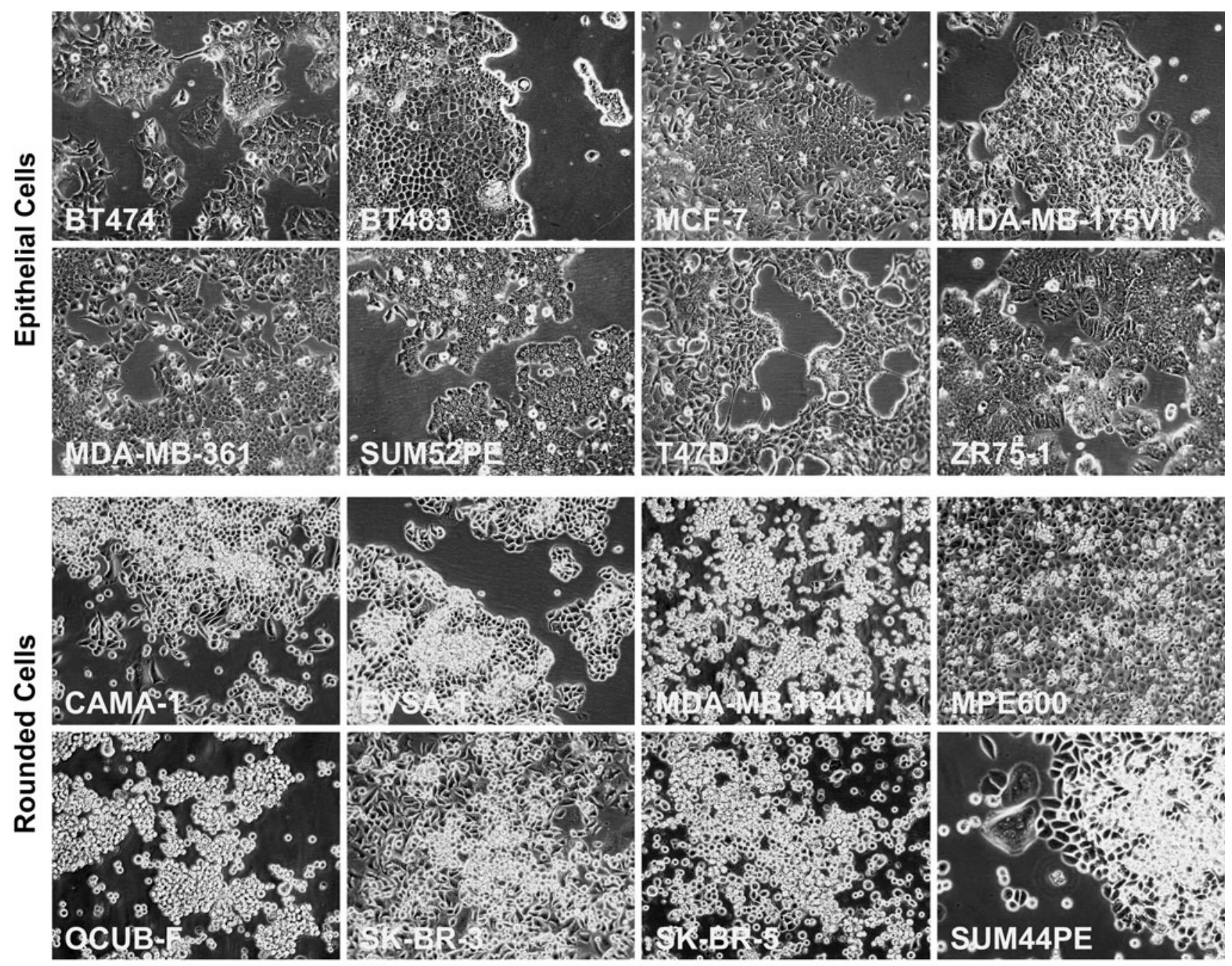
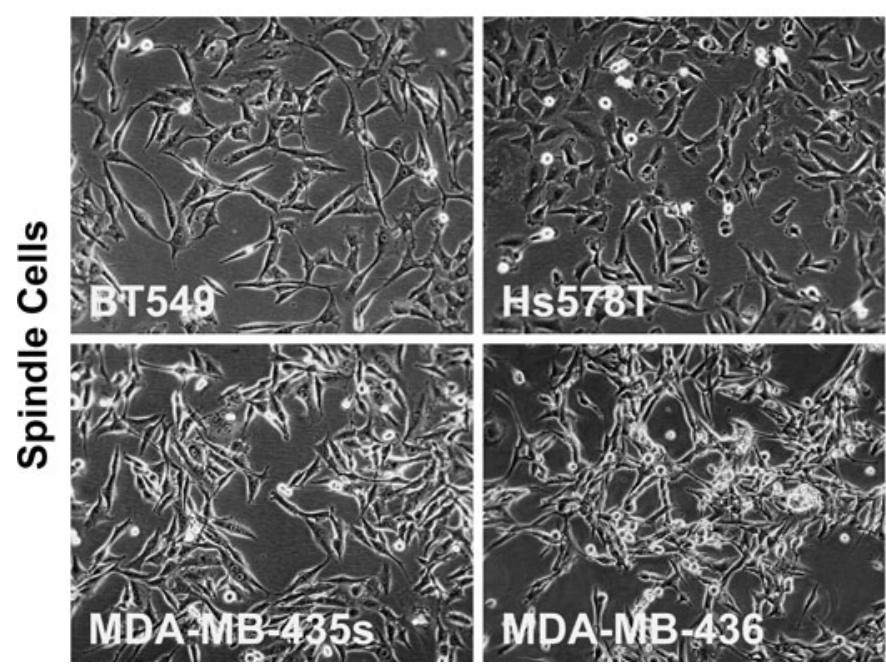

Fig. 1 Morphology of human breast cancer cell lines. Eight examples are given for each of three morphology groups: epithelial cells that all have wild-type E-cadherin genes and normal E-cadherin protein

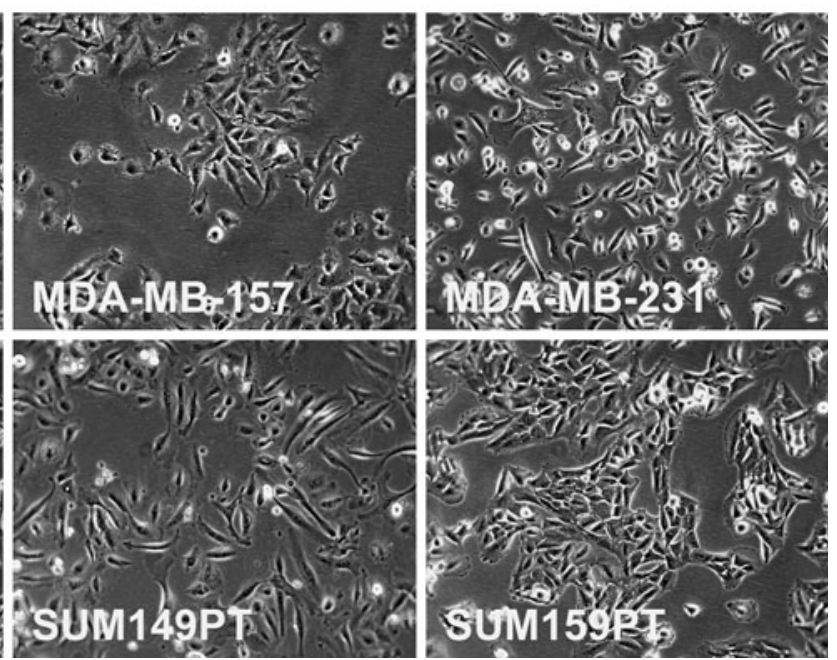

expression; rounded cells that all have mutant E-cadherin genes; and spindle cells that all have methylation at the E-cadherin promoter region 


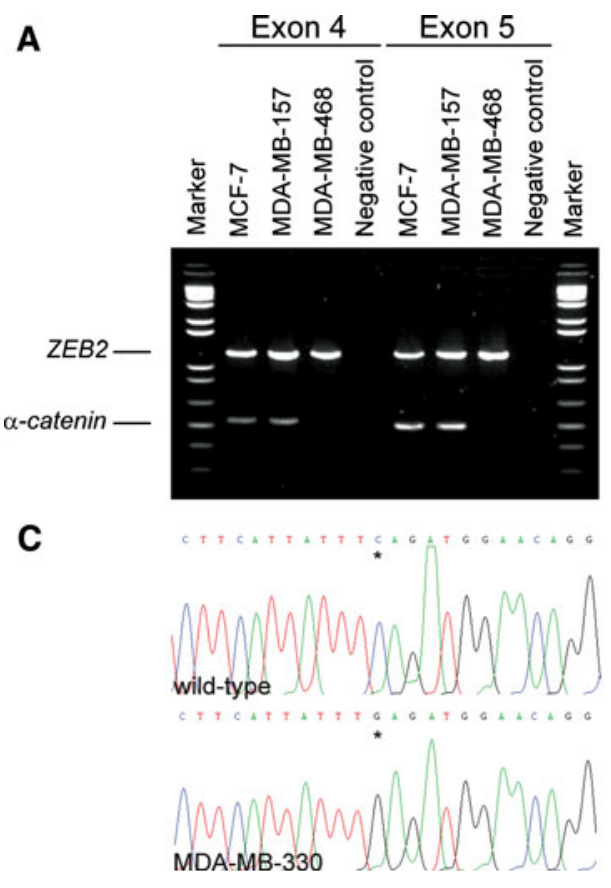

Fig. 2 Identification of $\alpha$-catenin gene mutations among 55 breast cancer cell lines. a Homozygous deletion of exons 4 and 5 of $\alpha$-catenin in cell line MDA-MB-468 and $\mathbf{b}$ Homozygous deletion of exons 8 and 9 of $\alpha$-catenin in cell line MDA-MB-157. Duplex PCR amplification products are shown for three breast cancer cell lines, using primers specific for ZEB2 and $\alpha$-catenin (upper and lower fragments, respectively). Negative control, template negative control;

together, 14 out of the 55 breast cancer cell lines from our collection had the rounded cell morphology, with three of these carrying biallelic inactivating mutations in $\alpha$-catenin and the other 11 carrying biallelic inactivating mutations in E-cadherin. Our results thus support $\alpha$-catenin as a putative new tumor suppressor gene in the E-cadherin tumor suppressor pathway.

Loss of $\alpha$-catenin protein expression associates with clinical lobular breast cancers

To substantiate our premise that $\alpha$-catenin operates in the E-cadherin tumor suppressor pathway, we have evaluated $\alpha$-catenin protein expression in clinical breast cancers.

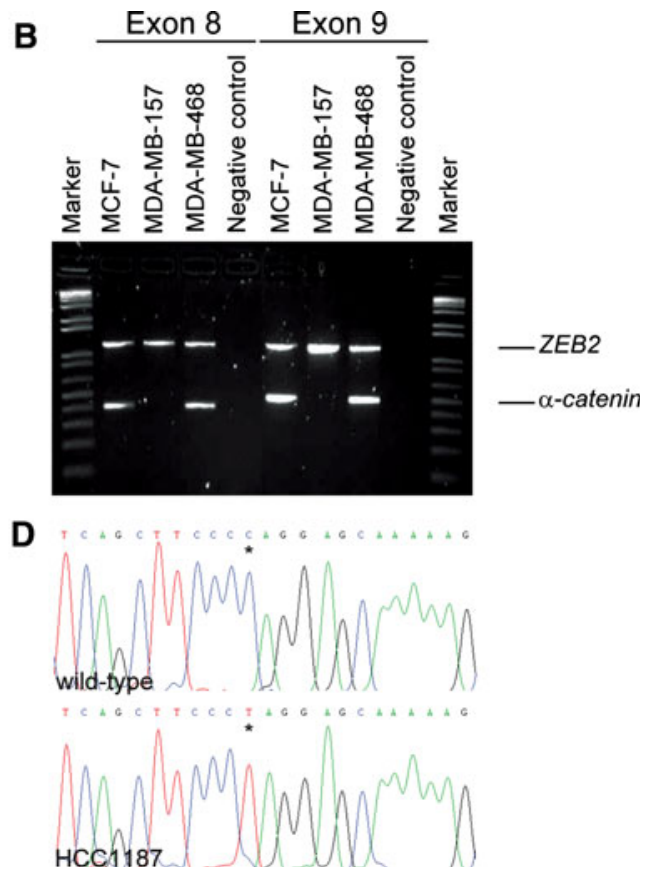

Marker, size marker $1 \mathrm{~kb}+$ DNA ladder (Invitrogen). c $\alpha$-catenin nonsense mutation identified in MDA-MB-330 and $\mathbf{d} \alpha$-catenin nonsense mutation identified in HCC1187. Mutations were identified by PCR amplification and sequencing of genomic DNA (lower electropherograms). The wild-type $\alpha$-catenin gene sequence is shown for comparison (top electropherograms)

Therefore, we have constructed a tissue microarray of 139 formalin-fixed paraffin-embedded (FFPE) primary breast cancers that included five pathological subtypes of breast carcinoma. Protein expression analysis by immunohistochemistry revealed absence of $\alpha$-catenin protein expression in 14 out of 139 tumors (10\%) and absence of E-cadherin protein expression in 37 of 139 tumors (27\%), with 13 tumors that had lost expression of both proteins (Table 2). As expected, loss of E-cadherin protein expression was particularly pronounced among lobular breast cancers (79\% of 33 tumors) and did not exceed $20 \%$ of tumors from other pathological subtypes. Most important, loss of $\alpha$-catenin protein expression was also particularly pronounced among lobular breast cancers (33\% of 33 tumors) and did not

Table 2 E-cadherin and $\alpha$-catenin protein expression among 139 clinical breast cancers

\begin{tabular}{|c|c|c|c|c|}
\hline Pathological subtype & $\begin{array}{l}\text { No. of } \\
\text { tumors }\end{array}$ & $\begin{array}{l}\text { Loss of } \alpha \text {-catenin } \\
\text { protein expression }\end{array}$ & $\begin{array}{l}\text { Loss of E-cadherin } \\
\text { protein expression }\end{array}$ & $\begin{array}{l}\text { Loss of } \alpha \text {-catenin and } \\
\text { E-cadherin protein expression }\end{array}$ \\
\hline Lobular & 33 & $11 / 33(33 \%)$ & $26 / 33(79 \%)$ & $11 / 33(33 \%)$ \\
\hline Ductal & 48 & $2 / 48(4 \%)$ & $4 / 48(8 \%)$ & $1 / 48(2 \%)$ \\
\hline Mucinous & 22 & $1 / 22(4 \%)$ & $4 / 22(18 \%)$ & $1 / 22(5 \%)$ \\
\hline Medullary & 22 & $0 / 22(0 \%)$ & $3 / 22(14 \%)$ & $0 / 22(0 \%)$ \\
\hline Tubular & 14 & $0 / 14(0 \%)$ & $0 / 14(0 \%)$ & $0 / 14(0 \%)$ \\
\hline Total & 139 & $14 / 139(10 \%)$ & $37 / 139(27 \%)$ & $13 / 139(9 \%)$ \\
\hline
\end{tabular}


exceed $5 \%$ in the other subtypes (Table 2). Loss of $\alpha$ catenin protein expression thus was significantly associated with breast cancers of the lobular subtype $(\chi 2, P<0.001)$, supporting our observation that $\alpha$-catenin may be a tumor suppressor that operates in the E-cadherin pathway.

\section{Discussion}

We have identified four human breast cancer cell lines with biallelic inactivating $\alpha$-catenin mutations among 55 human breast cancer cell lines, suggesting that $\alpha$-catenin is a new tumor suppressor gene. Similar to the E-cadherin mutant breast cancer cell lines, three of the $\alpha$-catenin mutant cell lines had the rounded cell morphology. All four $\alpha$-catenin mutant breast cancer cell lines had lost $\alpha$-catenin protein expression and, concordantly, loss of $\alpha$-catenin protein expression was most pronounced among clinical breast cancers of lobular pathology. It was therefore quite surprising that we detected only two $\alpha$-catenin gene mutations among 107 fresh-frozen lobular breast cancers and $12 \alpha$ catenin-negative paraffin-embedded breast cancers, both of which were of unclear oncogenic significance (data not shown). The question arises whether we have failed to detect $\alpha$-catenin mutations in the clinical cancer samples or that we have not analyzed the appropriate sample cohort. In this respect, diffuse-type gastric cancer is a likely candidate, particularly because both somatic and germline E-cadherin mutations have been associated specifically with this tumor type $[8,9,19,20]$.

Pending identification of $\alpha$-catenin mutations in clinical tumor samples, the argument for $\alpha$-catenin as a new tumor suppressor gene is compelling. The four $\alpha$-catenin mutant breast cancer cell lines that we identified here all had biallelic mutations that predicted premature termination of the encoded proteins - a classical hallmark of a tumor suppressor gene. But even more convincing was the mutual exclusive occurrence of $\alpha$-catenin and E-cadherin gene mutations in breast cancer cell lines with the rounded cell morphology. Rounded cells with scant cytoplasm is a defining feature of lobular breast cancers as well as diffusetype gastric cancers. In concordance, $\alpha$-catenin mutations were shown to be causative for the diminished cell adhesion in $\alpha$-catenin mutant cell lines [21-24]. Together, these results strongly suggest that $\alpha$-catenin and E-cadherin operate in the same tumor suppressor pathway. Our observation that $\alpha$-catenin and E-cadherin protein expression was lost predominantly among clinical lobular breast cancers further substantiates the functional relationship between the two proteins. Whatever the mutation detection method, the tumor type or subtype, it seems a matter of time and effort that $\alpha$-catenin mutations are found in clinical tumors.
Acknowledgments Grant support: Susan G. Komen Breast Cancer Foundation (BCTR0601309), Erasmus MC Mrace 2005 and Netherlands Genomics Initiative (NGI)/Netherlands Organization for Scientific Research (NWO). We thank Adrian Mombrun and Thierry van de Wetering for technical assistance.

\section{References}

1. Gumbiner BM (2005) Regulation of cadherin-mediated adhesion in morphogenesis. Nat Rev Mol Cell Biol 6:622-634

2. van Roy F, Berx G (2008) The cell-cell adhesion molecule E-cadherin. Cell Mol Life Sci 65(23):3756-3788

3. Berx G, Van Roy F (2001) The E-cadherin/catenin complex: an important gatekeeper in breast cancer tumorigenesis and malignant progression. Breast Cancer Res 3:289-293

4. Hajra KM, Fearon ER (2002) Cadherin and catenin alterations in human cancer. Genes Chromosomes Cancer 34:255-268

5. Peinado H, Olmeda D, Cano A (2007) Snail, Zeb and bHLH factors in tumour progression: an alliance against the epithelial phenotype? Nat Rev Cancer 7:415-428

6. Berx G, Cleton-Jansen AM, Nollet F, de Leeuw WJ, van de Vijver M, Cornelisse C, van Roy F (1995) E-cadherin is a tumour/invasion suppressor gene mutated in human lobular breast cancers. Embo J 14:6107-6115

7. Berx G, Cleton-Jansen AM, Strumane K, de Leeuw WJ, Nollet F, van Roy F, Cornelisse C (1996) E-cadherin is inactivated in a majority of invasive human lobular breast cancers by truncation mutations throughout its extracellular domain. Oncogene 13: 1919-1925

8. Becker KF, Atkinson MJ, Reich U, Huang HH, Nekarda H, Siewert JR, Hofler H (1993) Exon skipping in the E-cadherin gene transcript in metastatic human gastric carcinomas. Hum Mol Genet 2:803-804

9. Becker KF, Atkinson MJ, Reich U, Becker I, Nekarda H, Siewert JR, Hofler H (1994) E-cadherin gene mutations provide clues to diffuse type gastric carcinomas. Cancer Res 54:3845-3852

10. Derksen PW, Liu X, Saridin F, van der Gulden H, Zevenhoven J, Evers B, van Beijnum JR, Griffioen AW, Vink J, Krimpenfort P, Peterse JL, Cardiff RD, Berns A, Jonkers J (2006) Somatic inactivation of E-cadherin and p53 in mice leads to metastatic lobular mammary carcinoma through induction of anoikis resistance and angiogenesis. Cancer Cell 10:437-449

11. Graff JR, Herman JG, Lapidus RG, Chopra H, Xu R, Jarrard DF, Isaacs WB, Pitha PM, Davidson NE, Baylin SB (1995) E-cadherin expression is silenced by DNA hypermethylation in human breast and prostate carcinomas. Cancer Res 55:5195-5199

12. van de Wetering M, Barker N, Harkes IC, van der Heyden M, Dijk NJ, Hollestelle A, Klijn JG, Clevers H, Schutte M (2001) Mutant E-cadherin breast cancer cells do not display constitutive Wnt signaling. Cancer Res 61:278-284

13. Hollestelle A, Nagel JHA, Smid M, Lam S, Elstrodt F, Wasielewski M, Ng S, French PJ, Peeters JK, Rozendaal MJ, Riaz M, Koopman DG, ten Hagen TLM, de Leeuw HCGM, Zwarthoff EC, Teunisse A, van der Spek PJ, Klijn JGM, Dinjens WNM, Ethier SP, Clevers H, Jochemsen AG, den Bakker MA, Foekens JA, Martens JWM, Schutte M (2009) Distinct gene mutation profiles among luminal-type and basal-type breast cancer cell lines. Breast Cancer Res Treat. doi:10.1007/s10549-009-0460-8

14. Lei H, Sjoberg-Margolin S, Salahshor S, Werelius B, Jandakova E, Hemminki K, Lindblom A, Vorechovsky I (2002) CDH1 mutations are present in both ductal and lobular breast cancer, but promoter allelic variants show no detectable breast cancer risk. Int J Cancer 98:199-204 
15. Tavassoli FA, Devilee P, International Agency for Research on Cancer, World Health Organization (2003) Pathology and genetics of tumours of the breast and female genital organs. International Agency for Research on Cancer; Oxford University Press (distributor), Lyon, Oxford

16. Cailleau R, Olive M, Cruciger QV (1978) Long-term human breast carcinoma cell lines of metastatic origin: preliminary characterization. In Vitro 14:911-915

17. Cailleau R, Young R, Olive M, Reeves WJ Jr (1974) Breast tumor cell lines from pleural effusions. J Natl Cancer Inst 53:661-674

18. Engel LW, Young NA (1978) Human breast carcinoma cells in continuous culture: a review. Cancer Res 38:4327-4339

19. Guilford P, Hopkins J, Harraway J, McLeod M, McLeod N, Harawira P, Taite H, Scoular R, Miller A, Reeve AE (1998) Ecadherin germline mutations in familial gastric cancer. Nature 392:402-405

20. Guilford PJ, Hopkins JB, Grady WM, Markowitz SD, Willis J, Lynch H, Rajput A, Wiesner GL, Lindor NM, Burgart LJ, Toro TT, Lee D, Limacher JM, Shaw DW, Findlay MP, Reeve AE
(1999) E-cadherin germline mutations define an inherited cancer syndrome dominated by diffuse gastric cancer. Hum Mutat $14: 249-255$

21. Watabe M, Nagafuchi A, Tsukita S, Takeichi M (1994) Induction of polarized cell-cell association and retardation of growth by activation of the E-cadherin-catenin adhesion system in a dispersed carcinoma line. J Cell Biol 127:247-256

22. Ewing CM, Ru N, Morton RA, Robinson JC, Wheelock MJ, Johnson KR, Barrett JC, Isaacs WB (1995) Chromosome 5 suppresses tumorigenicity of $\mathrm{PC} 3$ prostate cancer cells: correlation with re-expression of alpha-catenin and restoration of E-cadherin function. Cancer Res 55:4813-4817

23. Bullions LC, Notterman DA, Chung LS, Levine AJ (1997) Expression of wild-type alpha-catenin protein in cells with a mutant alpha-catenin gene restores both growth regulation and tumor suppressor activities. Mol Cell Biol 17:4501-4508

24. Maeno Y, Moroi S, Nagashima H, Noda T, Shiozaki H, Monden M, Tsukita S, Nagafuchi A (1999) Alpha-catenin-deficient F9 cells differentiate into signet ring cells. Am J Pathol 154:13231328 